\title{
Glucose-inducible hypertrophy and suppression of anion efflux in rat beta cells
}

\author{
C B Chan, M C Saleh, A Purje and R M MacPhail \\ Department of Anatomy and Physiology, Atlantic Veterinary College, University of Prince Edward Island, 550 University Avenue, Charlottetown PEl C1A 4P3, \\ Canada \\ (Requests for offprints should be addressed to C B Chan; Email: cchan@upei.ca)
}

\begin{abstract}
Hypertrophy of beta cells from obese $f a / f a$ rats is associated with increased sensitivity to basal glucose. Exposure to glucose in culture distorts insulin secretion more in beta cells from large than small islets from $f a / f a$ rats. The aim of the present study is to investigate whether increased beta cell volume is associated with both glucose hypersensitivity and altered activity of the glucose-sensitive anion conductance. Beta cells from $f a / f a$ rats had increased volume compared with those from lean rats after $24 \mathrm{~h}$ culture. Three-day exposure to $25 \mathrm{mM}$ glucose in culture induced $10-15 \%$ hypertrophy in beta cells from lean rats and basal secretion from intact islets was increased tenfold. Estimates of ion channel activity were made from measurement of radiolabeled ion efflux. Taurine efflux, a marker of glucose-regulated anion channel activity, was reduced after high glucose exposure but no alterations in glucosedependent $\mathrm{K}^{+}$efflux were detected. The reverse hemolytic plaque assay was used to determine the contributions of the number of secreting cells (recruitment) versus
\end{abstract}

secretion per cell in beta cells from enlarged $(>250 \mu \mathrm{m}$ diameter), intermediate $(125-250 \mu \mathrm{m})$ and small $(<125 \mu \mathrm{m})$ islets from lean and obese rats exposed to conditions mimicking hyperglycemia. After overnight culture, basal secretion was twofold greater from beta cells of large $f a / f a$ islets compared with all other groups. Recruitment at low glucose was increased in all lean or $f a / f a$ beta cells derived from $>125 \mu \mathrm{m}$ islets. When beta cells from small islets were exposed to supra-physiological glucose for 3 days, recruitment was increased at basal glucose and blunted at high glucose. Glucose exposure converts the recruitment profile of beta cells from small islets to resemble that of beta cells from large islets while inducing cellular hypertrophy and reduced anion conductance. However, hypertrophy alone did not predict functional characteristics of overnight-cultured beta cells from $f a / f a$ rats.

Journal of Endocrinology (2002) 173, 45-52

\section{Introduction}

Short-term changes in cell volume are postulated to modulate cellular function, for example by altering second messenger system activity (Haussinger \& Lang 1991). Longer-term cell swelling might, however, be associated with pathological processes. In diabetesrelated conditions, cell swelling caused by exposure to high glucose is implicated in retinopathy (Wakisaka et al. 1999). Volume regulation of pancreatic beta cells can also be induced by glucose (Best 1997) or osmotic changes (Britsch et al. 1994). Exposure to glucose but not non-metabolized analogues leads to increased cell volume coincident with increased insulin secretion (Miley et al. 1997). The mechanism by which changes in cell volume affect beta cell function is proposed to be through activation of a volume-sensitive anion $\left(\mathrm{Cl}^{-}\right)$conductance (Best et al. 1996a,b). Combined with inactivation of the $\mathrm{K}_{\mathrm{ATP}}$-dependent channel, outward movement of anions would contribute to beta cell depolarization (Best 1997).

In obesity, enlargement of pancreatic islets is a classic observation in both human subjects and rodent models. In the $f a / f a$ Zucker rat, such enlargement has been attributed to both hyperplasia and hypertrophy of the beta cells (Hayek \& Woodside 1979). If volume is inferred from published data on average beta cell area from islets isolated from lean and obese rats, an outcome of $30-60 \%$ increased volume per beta cell is calculated (Chan et al. 1999). Since beta cell mass of similar-aged $\mathrm{fa} / \mathrm{fa}$ rats is reported to be approximately double that of controls (Pick et al. 1998), then as much as half of the increase might be attributable to an increase in cell volume. Previously, cellular hypertrophy in $f a / f a$ rats was associated with basal glucose hypersensitivity and reduced expression of exocytotic proteins (Chan et al. 1999). This study was undertaken to determine if changes in the volume-sensitive anion conductance might 
contribute to beta cell hypertrophy associated with altered glucose responsiveness.

\section{Materials and Methods}

\section{Animals}

Lean and obese $(f a / f a)$ 8-week-old Zucker rats of both sexes were obtained from Charles River Laboratories (St Constant, QC, Canada) and cared for in accordance with the principles of laboratory animal care and the regulations of the Canadian Council on Animal Care, vol. I and II. Standard chow (Purina 5001, Ralston Purina, St Louis, MO, USA) and water were provided and the animals allowed to feed ad libitum. The rats were fasted overnight prior to any experimental procedures, which were performed under sodium pentobarbital anesthesia $(60 \mathrm{mg} / \mathrm{kg}$ i.p.). A fasted blood sample was obtained by cardiac puncture just prior to islet isolation. A fed blood sample was obtained from the tail vein of the rats 3-4 days prior to islet isolation.

\section{Islet isolation and culture}

Pancreatic islets were isolated as described (Kibenge \& Chan 1995). Islets from $f a / f a$ rats were divided into small $(<125 \mu \mathrm{m}$, faSM), intermediate $(<250 \mu \mathrm{m}$ but $>125 \mu \mathrm{m}$, faINT) or large $(>250 \mu \mathrm{m}$, faLG) diameter groups, as in previous studies (Chan et al. 1999). Although 8-week-old lean rats have some islets $>250 \mu \mathrm{m}$ in size, these account for a very small proportion of the islets liberated by the isolation process. Thus, lean rat islets were sub-divided into $<125 \mu \mathrm{m}(\mathrm{LnSM})$ and $>125 \mu \mathrm{m}$ (LnINT) groups. The culture medium was Dulbecco's modified Eagle's medium (Gibco/BRL, Burlington, ON, Canada) containing 12.5 or $25.0 \mathrm{mM}$ glucose, supplemented with $10 \mathrm{mM}$ HEPES (Sigma), 1\% antibiotic/antimycotic solution (Sigma), and 10\% calf serum (Gibco/BRL) (final concentrations). These glucose concentrations were previously shown to induce more rapid alterations in secretory function in islets from $f a / f a$ rats compared with lean controls (Chan et al. 1996). The islets were maintained in an environment of humidified $95 \%$ air and $5 \% \mathrm{CO}_{2}$ at $37^{\circ} \mathrm{C}$. Insulin secretion from intact islets was measured as described previously (Kibenge \& Chan 1995). For studies of individual beta cells, islets were exposed to PBS ( $\mathrm{pH}$ $7 \cdot 4)$ containing trypsin $(0 \cdot 016 \%)$ and EDTA $(0 \cdot 2 \mathrm{mM})$ for 11 (small) to $15 \mathrm{~min}$ (large). The digestion was stopped by thoroughly washing the cells in fresh PBS.

\section{Beta cell area measurement}

Beta cells were mounted on glass slides as described below for the reverse hemolytic plaque assay. At least 50 cells from each islet size group per rat were quantified using computer-assisted morphometry of video images transmitted via a Zeiss microscope at a magnification of $1026 \times$. The software was from Bioquant ( $R$ \& $M$ Biometrics, Nashville, TN, USA). Cell volumes were computed from the area measurements, assuming a spherical shape.

\section{Estimation of ion channel activity}

Efflux from pre-loaded islets of ${ }^{86} \mathrm{Rb}^{+}$as a tracer for $\mathrm{K}^{+}$ was used to assess activity of ATP-dependent $\mathrm{K}^{+}\left(\mathrm{K}_{\mathrm{ATP}}\right)$ channels as described previously (Chan \& MacPhail 1996). The activity of volume-sensitive anion channels was assessed by estimating efflux from pre-loaded cells of $\left[{ }^{3} \mathrm{H}\right]$ taurine, essentially as described by Best \& Benington (1998). Briefly, batches of 100 islets incubated in buffer containing (mM) NaCl (135), $\mathrm{KCl}$ (5), $\mathrm{MgSO}_{4}$ (1) $\mathrm{NaH}_{2} \mathrm{PO}_{4}(1), \mathrm{CaCl}_{2}(1 \cdot 2)$, glucose (0.5) and HEPES (10, $\mathrm{pH} 7 \cdot 4)$ and $4 \mu \mathrm{Ci}\left[{ }^{3} \mathrm{H}\right]$ taurine for $2 \mathrm{~h}$ at $37^{\circ} \mathrm{C}$. After washing extensively to remove extracellular tracer, the islets were resuspended in fresh medium containing glucose and other reagents as indicated in the Results. Test glucose concentrations were the same as those used by others (Best \& Benington 1998) in order to facilitate comparisons. Isotonicity was maintained by adding isosmotic glucose solution $(308 \mathrm{mM})$ and reducing the volume of $\mathrm{NaCl}$ accordingly. At 5-min intervals, the supernatant was removed and fresh solutions added for a total of $20 \mathrm{~min}$. At termination of the experiment, supernatant and islet pellets were resuspended in scintillation medium for liquid scintigraphy.

\section{Reverse hemolytic plaque assay (RHPA) for beta cells}

Insulin secretory activity of individual beta cells was assessed using a RHPA as described previously (Chan et al. 1998). This assay permits assessment of the activity of individual hormone-secreting cells (Smith \& Neill 1987). Beta cells were exposed to glucose $(1.4-16.5 \mathrm{mM})$ plus insulin antibody for $2 \mathrm{~h}$, then guinea pig complement for $30 \mathrm{~min}$. At the termination of the experiment, the cells were fixed with $1.0 \%$ glutaraldehyde in $0.04 \mathrm{M}$ phosphate buffer ( $\mathrm{pH} \mathrm{7.5)}$ for $15 \mathrm{~min}$, then transferred to $0.01 \mathrm{M}$ PBS ( $\mathrm{pH} 7 \cdot 4$ ) and stored at $4{ }^{\circ} \mathrm{C}$ until immunostained for insulin. For each slide, recruitment, defined as the proportion of secreting beta cells, was assessed by light microscopy. Depending on cell density, 50-200 cells per slide were categorized. Insulin-positive cell doublets or clumps were not included in the totals. Computer-assisted measurement of plaque and cell areas was carried out using the Bioquant IV ( $\mathrm{R} \& \mathrm{M}$ Biometrics) software package. Plaque areas were quantified only for $2.8,8.3$ and $16.5 \mathrm{mM}$ glucose, representing baseline, half-maximal, and maximal glucose concentrations with respect to recruitment for the majority of the populations tested. 
Table 1 Effect of culture conditions on individual beta cell area and calculated volume. $n: x=$ the number of islet donors: the total number of cells quantified. Units are $\mu \mathrm{m}^{2}$ for area (A) and $\mu \mathrm{m}^{3}$ for volume $(\mathrm{V})$. Volumes were calculated from area data assuming a spherical shape of the cells

\begin{tabular}{|c|c|c|c|c|}
\hline & & $\begin{array}{l}\text { Cultured } \\
\text { overnight - } \\
12 \cdot 5 \mathrm{mM} \text { glucose }\end{array}$ & $\begin{array}{l}\text { Cultured } 3 \\
\text { days - } \\
12 \cdot 5 \mathrm{mM} \text { glucose }\end{array}$ & $\begin{array}{l}\text { Cultured } 3 \\
\text { days - } \\
25 \cdot 0 \mathrm{mM} \text { glucose }\end{array}$ \\
\hline \multicolumn{5}{|l|}{$\begin{array}{l}\text { Islet } \\
\text { donor }\end{array}$} \\
\hline \multirow[t]{2}{*}{ LnSM } & A & $117 \cdot 7 \pm 1 \cdot 6(8: 1130)$ & $126 \cdot 5 \pm 1 \cdot 5(8: 540)$ & $136 \cdot 5 \pm 3 \cdot 0(7: 425)^{*}$ \\
\hline & $\mathrm{V}$ & 961 & 1070 & 1200 \\
\hline \multirow[t]{2}{*}{ LnINT } & A & $128 \cdot 54 \pm 2 \cdot 1(9: 457)$ & ND & ND \\
\hline & V & 1096 & & \\
\hline \multirow[t]{2}{*}{ faSM } & A & $134 \cdot 7 \pm 3 \cdot 0(5: 629)$ & ND & $147 \cdot 2 \pm 4 \cdot 7(4: 227)^{*}$ \\
\hline & V & 1176 & & 1343 \\
\hline \multirow[t]{2}{*}{ falNT } & A & $148 \cdot 1 \pm 2 \cdot 8(6: 367)^{*}$ & ND & ND \\
\hline & V & 1356 & & \\
\hline \multirow[t]{2}{*}{ faLG } & A & $137 \cdot 4 \pm 1 \cdot 9(7: 931)^{*}$ & ND & ND \\
\hline & V & 1212 & & \\
\hline
\end{tabular}

${ }^{*} P<0.05$ compared with LnSM islet donors. ND, not done.

Images were transmitted via a Zeiss microscope and video camera for viewing at a final magnification of $1026 \times$ on a computer screen.

\section{Statistical analysis of data}

Data in the Results section are reported as means \pm S.E. unless otherwise stated. For beta cell studies, the number of individual islet donor rats and the total number of cells quantified are indicated as ' $n: x$ '. Significant differences in the recruitment were determined using $\chi^{2}$ analysis with the Bonferroni adjustment for multiple comparisons using Minitab version 8.3 software (Minitab Inc., State College, $\mathrm{PA}$, USA). The $\mathrm{EC}_{50}$ values for concentration-response curves were calculated using GraphPad Prism (version 3.0 for Windows, GraphPad Software, San Diego, CA, USA, www.graphpad.com). All other comparisons were conducted using ANOVA (Minitab). Differences were considered significant if $P<0 \cdot 05$ or better.

\section{Results}

\section{Plasma glucose concentrations}

There was no significant difference in plasma glucose concentrations of fasted lean vs $f a / f a$ rats $(6 \cdot 4 \pm 0 \cdot 7$ vs $7 \cdot 0 \pm 0.3 \mathrm{mM}, P>0.05)$. However, in unstarved rats, plasma glucose concentration of $f a / f a$ rats was $8.6 \pm 0.4 \mathrm{mM}$, compared with $7 \cdot 7 \pm 0.4 \mathrm{mM}$ in lean animals $(P<0 \cdot 05)$.

\section{Beta cell size}

Cell area in 24 and $72 \mathrm{~h}$ cultured beta cells was measured (Table 1). After $24 \mathrm{~h}$ exposure to $12.5 \mathrm{mM}$ glucose, cell area was elevated by $15-30 \%$ in faINT and faLG compared with LnSM cells, consistent with previous findings (Chan et al. 1999). A similar trend to hypertrophy was noted in faSM beta cells, but this was not significant. Computed volume increases ranged from 25 to $40 \%$. After high glucose exposure for $72 \mathrm{~h}$, the areas of both faSM and LnSM beta cells became significantly enlarged. The volume increase was $15-25 \%$. In contrast, there was no significant increase in beta cell area after $72 \mathrm{~h}$ culture in $12.5 \mathrm{mM}$ glucose.

\section{Ion fluxes}

Metabolism of glucose activates a volume sensitive anion channel that transports mainly $\mathrm{Cl}^{-}$and potentiates cellular depolarization (Miley et al. 1997). Induction of cellular hypertrophy might alter the activity of this channel and contribute to the adaptation to glucose observed in lean rats. After culture for $24 \mathrm{~h}$ in $12.5 \mathrm{mM}$ glucose, ${ }^{3} \mathrm{H}-$ taurine efflux was $\sim 30 \%$ over $20 \mathrm{~min}$ in the presence of $0.5 \mathrm{mM}$ glucose. Efflux was elevated by $20 \mathrm{mM}$ glucose to $50 \%$ but in the presence of the anion channel blocker, 4, $4^{\prime}$-dithiocyanotostilbene- $2,2^{\prime}$-disulphonic acid (DIDS, $0 \cdot 1 \mathrm{mM}$ ), was not different than at low glucose (Fig. 1A). Three-day culture in $12.5 \mathrm{mM}$ glucose resulted in an overall suppression of taurine efflux, but the cells were still responsive to both glucose and DIDS. Exposure to chronically elevated glucose for $72 \mathrm{~h}$ markedly reduced channel activity in the presence of both $0.5 \mathrm{mM}$ and $20 \mathrm{mM}$ glucose (Fig. 1A) and DIDS did not effectively block taurine efflux.

Previously we showed that the altered glucose metabolism in islets of $f a / f a$ rats is paralleled by changes in $\mathrm{K}_{\text {ATP }}$ channel activity, such that by $5 \mathrm{mM}$ glucose ${ }^{86} \mathrm{Rb}^{+}$efflux was minimal and $15 \mathrm{mM}$ glucose had no further effect. In 
contrast, in lean rat islets a concentration-dependent closure of channels was evident from 0 to $15 \mathrm{mM}$ glucose (Chan \& MacPhail 1996). Therefore, we hypothesized that glucose exposure of the lean islets for $72 \mathrm{~h}$ might have either decreased ${ }^{86} \mathrm{Rb}^{+}$efflux at basal glucose that could explain elevated insulin release or that higher glucose would fail to suppress ${ }^{86} \mathrm{Rb}^{+}$efflux, consistent with the small degree of stimulation of insulin secretion observed. As shown in Fig. $1 \mathrm{~B},{ }^{86} \mathrm{Rb}^{+}$efflux was similar to control (overnight) values after $72 \mathrm{~h}$ of 12.5 or $25 \mathrm{mM}$ glucose
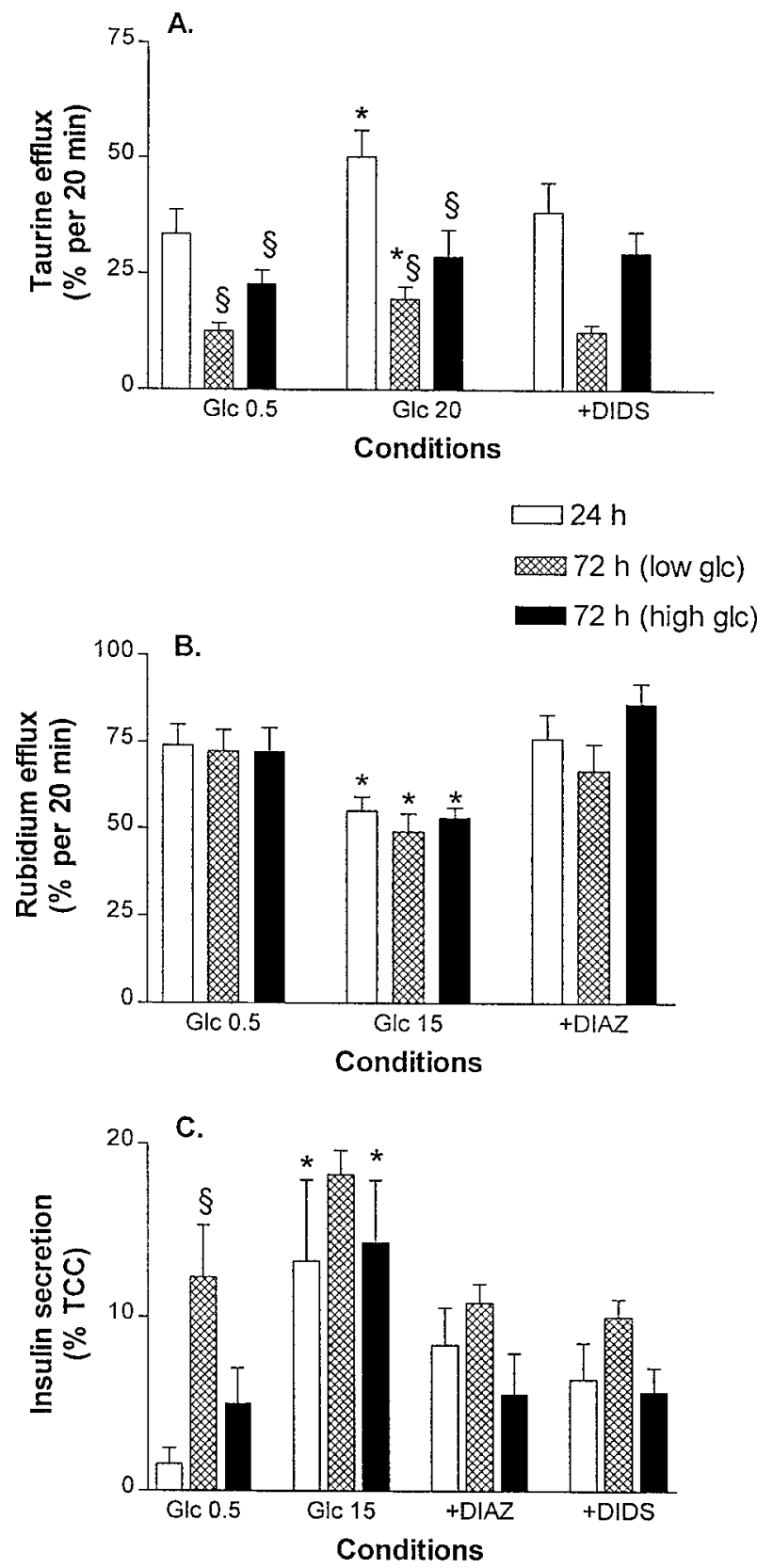

exposure. Similar sensitivity to the channel-opening agent diazoxide was also observed.

Insulin secretion from intact islets was also compared using glucose and the various channel modulators. As expected, basal insulin was elevated and glucosestimulated insulin secretion was blunted $(50 \%$ over basal) in islets cultured for $72 \mathrm{~h}$ in high glucose compared with $24 \mathrm{~h}$ cultured islets ( $850 \%$ over basal) (Fig. 1C). Three-day culture in $12.5 \mathrm{mM}$ resulted in slightly elevated basal secretion, and a glucose-stimulated insulin response of $\sim 325 \%$.

\section{Insulin secretory activity of beta cells}

Examination of insulin secretion by individual beta cells can reveal whether secretory changes are due to a change in the number of cells responsive to a particular glucose concentration (recruitment) or to altered secretion by each cell. The latter is assessed by measurement of plaque area in the RHPA. Secretory data can be correlated with individual beta cell size. The effects of culture glucose were compared using beta cells from small (SM) islets as for the ion flux experiments. These data were compared with those using beta cells from intermediate (INT) and large (LG) islets of both lean and $f a / f a$ rats.

Recruitment of beta cells from small islets of either lean or $f a / f a$ rats was $\sim 6 \%$ during exposure to basal glucose $(1 \cdot 4-4 \cdot 2 \mathrm{mM})$ after $24 \mathrm{~h}$ culture in $12.5 \mathrm{mM}$ glucose. In comparison, recruitment of beta cells in the faINT/LG and lnINT groups was significantly elevated $(12-18 \%$ at $2 \cdot 8 \mathrm{mM}$ ) (Fig. 2A and B). Increased sensitivity to low glucose was reflected by a left shift in the $\mathrm{EC}_{50}$ to glucose in faINT/LG beta cells (Table 2). In contrast, the maximum recruitment was suppressed in all fa-derived populations compared with lean-derived cells (Fig. 2). We

Figure 1 Effect of culture conditions on ion fluxes in LnSM and faSM islets. Intact islets were cultured for $24 \mathrm{~h}$ in medium with $12.5 \mathrm{mM}$ glucose or for $72 \mathrm{~h}$ with medium containing 12.5 or $25 \mathrm{mM}$ glucose. (A) Measurement of taurine efflux as a marker of volume-sensitive anion channel activity in the presence of low $(0.5 \mathrm{mM})$ or high $(20 \mathrm{mM})$ glucose $(\mathrm{Glc})$. The anion channel blocker, DIDS (0.1 mM), was added in the presence of $20 \mathrm{mM}$ glucose to demonstrate specificity of the measurement for volume-sensitive anion channel activity. $n=$ at least 9 for all conditions. ${ }^{*} P<0.05$ compared with $0.5 \mathrm{mM}$ glucose and $\S P<0.05$ compared with $24 \mathrm{~h}$ culture. (B) Measurement of Rb efflux as a marker of $\mathrm{K}_{\mathrm{ATP}}$ channel activity in the presence of low $(0.5 \mathrm{mM})$ or high $(15 \mathrm{mM})$ glucose. The $\mathrm{K}_{\mathrm{ATP}}$ channel opener diazoxide (DIAZ, $0 \cdot 1 \mathrm{mM}$ ) was added in the presence of $15 \mathrm{mM}$ glucose to demonstrate specificity of the measurement for $\mathrm{K}_{\text {ATP }}$ activity. $n=6$ for all conditions. ${ }^{*} P<0.05$ compared with $0.5 \mathrm{mM}$ glucose. (C) Insulin secretion by intact islets from lean rats in response to low glucose $(0.5 \mathrm{mM})$, and high glucose alone $(15 \mathrm{mM})$ in the presence of diazoxide $(0 \cdot 1 \mathrm{mM})$ or DIDS $(0 \cdot 1 \mathrm{mM})$. Secretion was measured for $90 \mathrm{~min}$ and is presented as \% of the total cell content (TCC) of the islets \pm S.E. for four experiments. ${ }^{*} P<0 \cdot 05$ compared with $0.5 \mathrm{mM}$ glucose and $\S P<0.05$ compared with $24 \mathrm{~h}$ culture. 

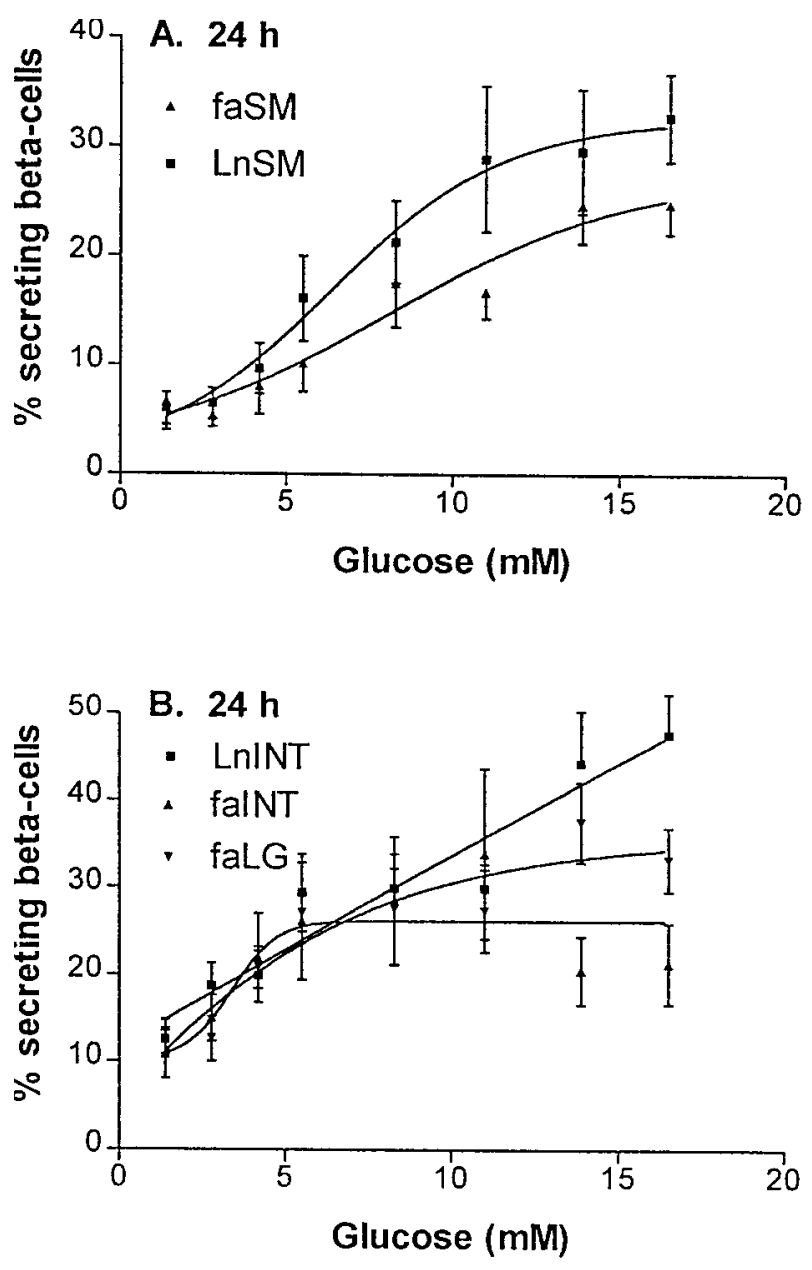

- LnSM-high glc

- faSM-high glc
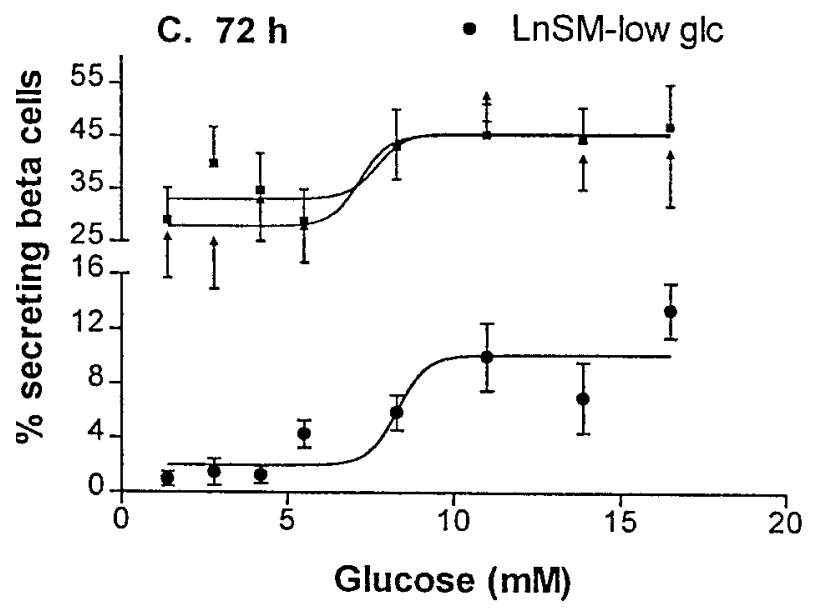

www.endocrinology.org predicted that by increasing the duration of culture and the glucose concentration, beta cells from small islets might exhibit functional properties more like those of larger islets. After $72 \mathrm{~h}$ culture in $25.0 \mathrm{mM}$ glucose, faSM and LnSM beta cells had a marked increase in recruitment to basal glucose $(25-40 \%$ at $2.8 \mathrm{mM}$ ) (Fig. 2C) compared with $72 \mathrm{~h}$ culture in $12.5 \mathrm{mM}$ glucose. Maximal recruitment reached about $45 \%$, which was higher than in $12.5 \mathrm{mM}$ cultured beta cells. Nonetheless, this represents a blunting of the glucose response, since the ratio of stimulated to basal secretion was approximately 1.5 for culture in $25 \mathrm{mM}$ glucose versus 3.5 for $24 \mathrm{~h}$ culture in $12.5 \mathrm{mM}$ glucose or 6.2 for $72 \mathrm{~h}$ culture in $12.5 \mathrm{mM}$ glucose. There was no change in the $\mathrm{EC}_{50}$ for glucose after $72 \mathrm{~h}$ culture at either glucose concentration (Table 2).

The plaque sizes (Fig. 3) were assessed to provide indices of secretion per cell (Smith \& Neill 1987). Mean plaque area was about $4000-5000 \mu \mathrm{m}^{2}$ for all groups except faLG beta cells, which averaged $7000-9000 \mu \mathrm{m}^{2}$. Except in LnSM beta cells there was no relationship between plaque area and glucose concentration. After $72 \mathrm{~h}$ culture, there was no discernible pattern in plaque areas (not shown).

\section{Discussion}

In obese animal models including the Zucker $f a / f a$ rat, pancreatic islet hypertrophy and hyperplasia are a classical finding (Shino et al. 1973, Larsson et al. 1977). In young adult Zucker rat islets, about half of the increase in islet volume may be attributed to beta cell hypertrophy (Chan et al. 1999). Why beta cells in obese rodents become enlarged is not clear but ambient hyperglycemia, such as was observed in this study, may be a factor. Moreover, hypertrophied beta cells from freshly isolated islets of fasted rats exhibit functional distinctions from smaller cells that appear to contribute to inappropriate glucose-stimulated insulin secretion. These differences include increased secretion at basal glucose levels and a reduction in insulin

Figure 2 Glucose responsiveness of individual beta cells (recruitment). (A) The recruitment of secretory beta cells (\%) from small islets $(<125 \mu \mathrm{m}$ diameter) from obese $(\boldsymbol{\Delta})$ and lean rats ( to a range of glucose concentrations after overnight culture in $12.5 \mathrm{mM}$ glucose. (B) The recruitment of secretory beta cells from intermediate $(>125 \mu \mathrm{m}$, lean $=\boldsymbol{\square}$, obese $=\boldsymbol{\Delta})$ and large $(>250 \mu \mathrm{m}, \boldsymbol{\nabla})$ islets after overnight culture in $12.5 \mathrm{mM}$ glucose. (C) The recruitment of secretory beta cells (\%) from small islets $(<125 \mu \mathrm{m}$ diameter) from obese $(\boldsymbol{\Delta})$ and lean rats $(\boldsymbol{\square})$ to a range of glucose concentrations after 3-day culture in $25 \mathrm{mM}$ glucose (high glc). The recruitment of secretory beta cells from lean rats after 3 days of culture in $12.5 \mathrm{mM}$ (low glc) glucose is shown for comparison ( ). Note the break in the Y-axis scale. The data are means \pm S.E.. The glucose concentrations eliciting half-maximal recruitment of secretory cells and $n$ for each group are reported in Table 2. 
Table 2 Glucose sensitivity $\left(\mathrm{EC}_{50}\right)$ of cultured beta cells. Units are $\mathrm{mM} \pm \mathrm{SE}$ for $(n)$ islet donors

\begin{tabular}{|c|c|c|c|}
\hline & $\begin{array}{l}\text { Cultured } \\
\text { overnight - } \\
12 \cdot 5 \mathrm{mM} \text { glucose }\end{array}$ & $\begin{array}{l}\text { Cultured } 3 \\
\text { days - } \\
12 \cdot 5 \mathrm{mM} \text { glucose }\end{array}$ & $\begin{array}{l}\text { Cultured } 3 \\
\text { days - } \\
25 \cdot 0 \mathrm{mM} \text { glucose }\end{array}$ \\
\hline \multicolumn{4}{|l|}{$\begin{array}{l}\text { Islet } \\
\text { donor }\end{array}$} \\
\hline LnSM & $6.35 \pm 0.97(8)$ & $8 \cdot 34 \pm 0 \cdot 54(8)$ & $7 \cdot 73 \pm 0.94(7)$ \\
\hline LnINT & NAC (9) & ND & ND \\
\hline faSM & $8 \cdot 09 \pm 2 \cdot 40(5)$ & ND & $7 \cdot 21 \pm 1 \cdot 99(4)$ \\
\hline falNT & $3 \cdot 66 \pm 0.92^{*}(6)$ & ND & ND \\
\hline faLG & $5 \cdot 00 \pm 1 \cdot 40(7)$ & ND & ND \\
\hline
\end{tabular}

${ }^{*} P<0.05$ compared with faSM beta cells by ANOVA. NAC, not able to calculate; ND, not done.

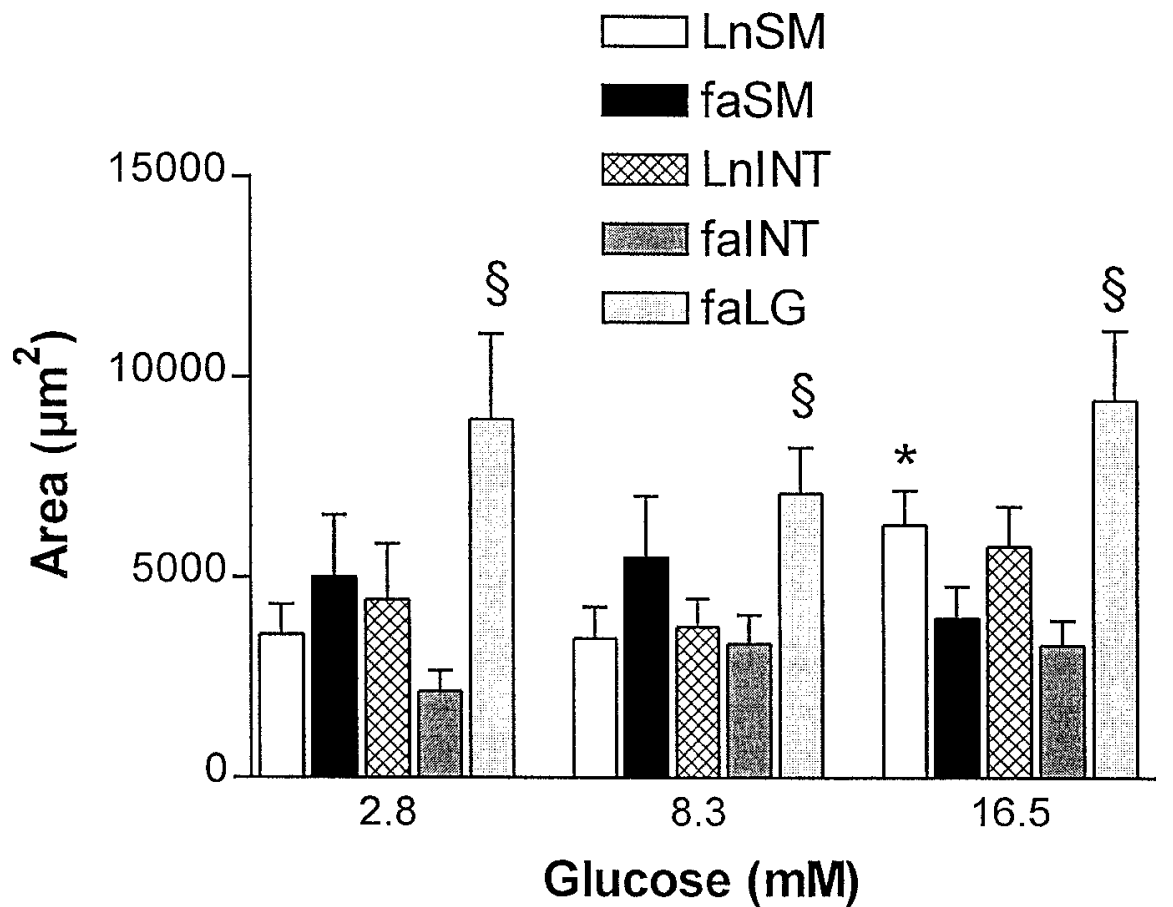

Figure 3 Estimation of secretion per beta cell, by quantification of plaque area $\left(\mu \mathrm{m}^{2}\right.$, mean \pm S.E.) generated by exposure of overnight-cultured beta cells to $2 \cdot 8,8 \cdot 3$ or $16.5 \mathrm{mM}$ glucose for beta cells from LnSM (open bars), faSM (solid bars), LnINT (cross-hatched bars), falNT (dark stipple) and faLG (light stipple) islet donors after overnight culture in $12.5 \mathrm{mM}$ glucose. Numbers of donor animals and cells are as for Table 2. ${ }^{*} P<0 \cdot 05$ compared with $2.8 \mathrm{mM}$ glucose, $\S P<0 \cdot 05$ compared with LnSM cells.

content after exposure to high glucose (Chan et al. 1999). Interestingly, larger beta cells from normal rats are more likely to secrete at physiological glucose levels (Giordano et al. 1993, Chan et al. 1999) but there is no size difference in secretory versus non-secretory cells from the largest islets of $f a / f a$ rats (Chan et al. 1999). In this study we examined the hypothesis that beta cell enlargement might be due to cellular swelling caused by environmental factors, such as glucose exposure. Our data show that extreme glucose exposure induces hypertrophy of normal beta cells that correlates with an increase in basal insulin secretion. The function of such beta cells was then compared with those of $f a / f a$ rats, which were already hypertrophied.

Three-day exposure to supra-physiological glucose concentrations induced swelling in lean rat beta cells $(25 \%)$ that was comparable to that measured in $f a / f a$ rats $(22-$ $41 \%)$. Acute exposure of beta cells to $20 \mathrm{mM}$ glucose invoked a $10-15 \%$ increase in cell volume that was maintained for the duration of the test (Miley et al. 1997). 
Basal insulin secretion from isolated islets was increased by tenfold. While the insulin response to higher glucose was not different from $24 \mathrm{~h}$ cultured islets, the fold increase over basal was blunted. These results are typical of sustained activation of beta cells (Ling \& Pipeleers 1996).

Because cell swelling can be induced by glucose to activate an anion conductance (Best 1997, Miley et al. 1997) and is correlated with an increase in insulin secretion (Britsch et al. 1994, Miley et al. 1997), we considered that activity of the glucose-sensitive anion channel might be increased after chronic glucose exposure.

A role for a glucose-sensitive anion conductance in beta cell signaling has just started to become appreciated, although the notion that $\mathrm{Cl}^{-}$fluxes can modulate insulin secretion was advanced more than 20 years ago (Sehlin 1978). This ATP-dependent channel was first described in 1995 by Kinard \& Satin and is likely $\mathrm{Cl}^{-}$conducting, based on pharmacological and electrical properties. The mechanism by which the anion conductance leads to beta cell depolarization is presumed to be a consequence of $\mathrm{Cl}^{-}$ efflux (Best et al. 1996a,b). By adding to the effects of $\mathrm{K}_{\mathrm{ATP}}$ channel inactivation, the intensity of electrical activity could be regulated (Best 1997). Therefore, sustained cell swelling induced by chronic exposure to high glucose might increase the activity of the volume-sensitive anion channel and contribute, in particular, to enhanced basal insulin secretion. In this study, the opposite effect was observed in that $\left[{ }^{3} \mathrm{H}\right]$ taurine efflux was decreased by about $30 \%$ at basal glucose and was not increased by elevated glucose in the chronically cultured cells. However, the generalized suppression of activity of the volume-sensitive anion channel by glucose exposure might contribute to the reduction in glucose-stimulated insulin secretion observed, since its role is to potentiate the depolarization of the beta cell induced by $\mathrm{K}_{\mathrm{ATP}}$ channel closure. Support for this conclusion is given by studies in which glucose-stimulated $\mathrm{Cl}^{-}$efflux was blunted in islets from obese diabetic $(d b / d b)$ mice (Berglund \& Sehlin 1980) concomitant with impaired insulin secretion. Since $d b / d b$ mice are markedly hyperglycemic, the notion that anion conductance is adversely affected by chronic glucose exposure is supported. However, $\mathrm{K}_{\mathrm{ATP}}$ channel activity was also abnormal in those mice (Berglund et al. 1978) but was not altered in the current study. In other cell types such as hepatocytes, cell swelling induces changes in metabolic processing of glucose by inhibiting glycogenolysis and glycolysis (Haussinger \& Lang 1991). The effects of volume changes on such processes in beta cells has not been examined.

The $f a / f a$ Zucker rat is a model of obesity that maintains relatively normal fasting glucose and glucose tolerance by compensatory increases in both basal and stimulated insulin secretion. Like $d b / d b$ mice, a genetic mutation renders the leptin receptor non-functional in $f a / f a$ rats (Chua et al. 1996) but the phenotype is not as severe. The obese rats we obtain from Charles River, Inc. consistently exhibit fasting glucose levels that are not significantly different from age-matched lean controls, yet average about 0.5 mM higher (Chan et al. 1999, Kibenge \& Chan 2001). However, single fasting measurements fail to capture information about $24 \mathrm{~h}$ glucose exposure of the beta cells. An increase in ambient plasma glucose concentrations was also observed in this study. These measurements were obtained from plasma collected near the beginning of the light cycle. The $f a / f a$ Zucker rat may have a disrupted diurnal rhythm such that serum glucose is more elevated during the dark hours (Martin et al. 1978). The possibility that glucose-induced swelling may contribute to beta cell hypertrophy in $f a / f a$ rat islets cannot be ruled out. To compare beta cell size with secretion patterns of beta cells from various populations of islets from both lean and obese rats, the RHPA was used.

After short-term culture in moderate glucose, beta cells isolated from larger islets from both lean and $f a / f a$ rats had elevated recruitment (number of actively secreting cells) at low glucose. There was no direct correlation with beta cell area, because faSM and faLG cells had a similar size distribution but faLG cells were two times more likely to secrete at $2.8 \mathrm{mM}$ glucose. Moreover, secretion per cell (plaque area) was similar in all beta cell groups except the faLG cells, which secreted approximately twofold more insulin independent of glucose concentration. Although extreme glucose exposure can induce hypertrophy and a secretory phenotype similar to that observed in enlarged beta cells from obese rats, it appears unlikely that the two phenomena are closely linked. Indeed, associations between insulin secretory patterns and beta cell volume are more closely linked in freshly isolated islets from fasted rats where glucose was reduced for approximately $18 \mathrm{~h}$, according to data from our previous study (Chan et al. 1999).

In conclusion, these studies have shown that chronic exposure to glucose does induce beta cell swelling. Unexpectedly, this was associated with a blunted response of the glucose-sensitive anion conductance. Therefore, chronic swelling is unlikely to account for enhanced basal secretion but may contribute to the failure of glucose to stimulate insulin release. Moreover, while exposure to glucose of normal beta cells from lean islets leads to a phenotype similar to that of beta cells from enlarged islets from obese rats, this congruence appears not to be related to hypertrophy-induced mechanisms per se. It is possible that beta cell enlargement is caused by glucose suppression of cell death but since beta cell turnover is normally very low, quantitative assessment of a further reduction is technically difficult.

\section{Acknowledgement}

This study was supported by the Medical Research Council of Canada. 


\section{References}

Berglund O \& Sehlin J 1980 Defective regulation of $\mathrm{Cl}^{-}$permeability in islets of diabetic mice [C57Bl/KsJ(db/db)]. Diabetes 29 151-155.

Berglund O, Sehlin J \& Täljedal I-B $1978{ }^{86} \mathrm{Rb}^{+}$fluxes and $\mathrm{K}^{+}$-stimulated nitrophenyl phosphatase activity in the pancreatic islets of genetically diabetic mice (C57BL/KsJ-db/db). Diabetologia 15 191-195.

Best L 1997 Glucose and $\alpha$-ketoisocaproate induce transient inward currents in rat pancreatic beta cells. Diabetologia 40 1-6.

Best L \& Benington S 1998 Effects of sulphonylureas on the volumesensitive anion channel in rat pancreatic $\beta$-cells. British Journal of Pharmacology 125 874-878.

Best L, Miley HE \& Yates AP 1996a Activation of an anion conductance and $\beta$-cell depolarization during hypotonically-induced insulin release. Experimental Physiology 81 927-933.

Best L, Sheader EA \& Brown PD 19966 A volume-activated anion conductance in insulin-secreting cells. Pflügers Archiv 431 363-370.

Britsch S, Krippeit-Drews P, Gregor M, Lang F \& Drews G 1994 Effects of osmotic changes in extracellular solution on electrical activity of mouse pancreatic B-cells. Biochemical and Biophysical Research Communications 204 641-645.

Chan CB \& MacPhail RM $1996 \mathrm{~K}_{\text {ATP }}$ channel-dependent and -independent pathways of insulin secretion in isolated islets from fa/fa Zucker rats. Biochemistry and Cell Biology 74 403-410.

Chan CB, Lowe JM \& Debertin WJ 1996 Modulation by glucose of insulin secretion and glucose phosphorylating activity in cultured pancreatic islets from obese (fa/fa) Zucker rats. International Journal of Obesity 20 175-184.

Chan CB, Wright GM, Wadowska DW, MacPhail RM, Ireland WP \& Sulston KW 1998 Ultrastructural and secretory heterogeneity of fa/fa (Zucker) rat islets. Molecular and Cellular Endocrinology 136 119-129.

Chan CB, MacPhail RM, Sheu L, Wheeler MB \& Gaisano HY 1999 $\beta$-Cell hypertrophy in $f a / f a$ rats is associated with basal glucose hypersensitivity and reduced SNARE protein expression. Diabetes 48 997-1005.

Chua SC, Chung WK, Wu-Peng XS, Zhang Y, Liu S-M, Tartaglia L \& Leibel RL 1996 Phenotypes of mouse diabetes and rat fatty due to mutations in the OB (leptin) receptor. Science 271 994-996.

Giordano E, Cirulli V, Bosco D, Rouiller D, Halban P \& Meda P 1993 B-cell size influences glucose-stimulated insulin secretion. American Journal of Physiology 265 C358-C364.

Haussinger D \& Lang F 1991 The mutual interaction between cell volume regulation and cell function: a new principle of metabolic regulation. Biochemistry and Cell Biology 69 1-4.
Hayek A \& Woodside W 1979 Correlation between morphology and function in isolated islets of the Zucker rat. Diabetes 28 565-569.

Kibenge MT \& Chan CB 1995 Identification of biochemical defects in pancreatic islets of $f a / f a$ rats: a developmental study. Obesity Research 3 171-178.

Kibenge MT \& Chan CB 2001 Interactions between effects of adrenalectomy and diet on insulin secretion in $f a / f a$ Zucker rats. Canadian Journal of Physiology and Pharmacology 79 1-7.

Kinard TA \& Satin LS 1995 An ATP-sensitive $\mathrm{Cl}^{-}$channel current that is activated by cell swelling, cAMP, and glyburide in insulin-secreting cells. Diabetes 44 1461-1466.

Larsson L-I, Boder GB \& Shaw WN 1977 Changes in the islets of Langerhans in the obese Zucker rat. Laboratory Investigation 36 593-598.

Ling Z \& Pipeleers DG 1996 Prolonged exposure of human $\beta$ cells to elevated glucose levels results in sustained cellular activation leading to a loss of glucose regulation. Journal of Clinical Investigation $\mathbf{9 8}$ 2805-2812.

Martin RJ, Wangsness PJ \& Gahagan JH 1978 Diurnal changes in serum metabolites and hormones in lean and obese Zucker rats. Hormone and Metabolic Research 19 187-192.

Miley HE, Sheader EA, Brown PD \& Best L 1997 Glucose-induced swelling in rat pancreatic beta-cells. Journal of Physiology $\mathbf{5 0 4}$ 191-198.

Pick A, Clark J, Kubstrup C, Levisetti M, Pugh W, Bonner-Weir S \& Polonsky KS 1998 Role of apoptosis in failure of $\beta$-cell mass compensation for insulin resistance and $\beta$-cell defects in the male Zucker diabetic fatty rat. Diabetes 47 358-364.

Sehlin J 1978 Interrelationships between chloride fluxes in pancreatic islets and insulin release. American Journal of Physiology $\mathbf{2 3 5}$ E501-E508.

Shino A, Matsueo T, Iwatsuka H \& Zuzuki Z 1973 Structural changes of pancreatic islets in genetically obese rats. Diabetologia 9 413-421.

Smith PF \& Neill JD 1987 Simultaneous measurement of hormone release and secretagogue binding by individual pituitary cells. PNAS 84 5501-5505.

Wakisaka M, Yoshinari M, Nakamura S, Asano T, Sonoki K, Ah S, Iwase M, Takata Y \& Fujishima M 1999 Suppression of sodiumdependent glucose uptake by captopril improves high-glucoseinduced morphological and functional changes of cultured bovine retinal pericytes. Microvascular Research 58 215-223.

Received 11 December 2001

Accepted 3 January 2002 